\title{
PENGARUH PEMBERIAN CACING SUTERA DENGAN PERSENTASE YANG BERBEDA TERHADAP KELANGSUNGAN HIDUP DAN PERTUMBUHAN LARVA IKAN BAUNG (Hemibagrus nemurus)
}

\section{Effect of Giving Silk Worms with Different Percentages to the Survival and Growth of Baung Fish Larvae (Hemibagus nemurus)}

\author{
Solihin, T. Iskandar Johan dan Agusnimar \\ Program Studi Budidaya Perairan \\ Fakultas PertanianUniversitas Islam Riau \\ [Diterima: Oktober 2018; Disetujui: Desember 2018]
}

\begin{abstract}
This research was conducted for 21 days starting from November 12 until December 2, 2017. Located at the Seed Fish Hall (BBI) Faculty of Agriculture, Islamic University of Riau Pekanbaru. The purpose of this research is to know the effect of silkworm with the different percentages on the survival and growth of baung larvae (H. nemurus). The method used was an experimental method using Completely Randomized Design (RAL) with 4 treatments and 3 replications namely, P1 (Giving silkworm 3\%/fish weight), P2 (Giving silkworm 6\%/fish weight), P3 (Giving silkworm 9\%/ weight of fish) and P4 (12\% silkworm/fish weight). The test fish used were larvae of 3-day-old bamboo fish with an average weight of $0.02 \mathrm{gr}$ and an average length of $0,7 \mathrm{~cm}$. Larva baung fish obtained from the spawning in the Seed Fish Hall (BBI) Faculty of Agriculture, Islamic University of Riau Pekanbaru. The container used is 10 liters or 10 liters capacity. From the research result, the best survival percentage on $\mathrm{P} 4$ is $90 \%$, then $\mathrm{P} 3$ is $89 \%$, then $\mathrm{P} 2$ is $87 \%$ and the lowest at P1 is $85 \%$. The absolute and absolute highest absolute growth is found in P4 weighing 0,28 gr and length 2.13 $\mathrm{cm}$, then P3 weighing 0,27 gr and length $2,10 \mathrm{~cm}$, then P2 weighing 0,26 gr and the next 2,07 cm length lowest on P1 weighing 0.24 gr and length of $2,03 \mathrm{~cm}$. The highest daily growth rate was also found in P4 13,81\%, P3 13,57\%, P2 13,32\%, and the lowest in P1 was 13,05\%.
\end{abstract}

Keywords: Silk Worms, Survival, Growth, Baung

ABSTRAK

Penelitan ini dilaksanakan selama 21 hari yaitu dimulai pada tanggal 12 November sampai 2 Desember 2017. Bertempat di Balai Benih Ikan (BBI) Fakultas Pertanian Universitas Islam Riau Pekanbaru. Tujuan dari penelitian ini adalah untuk mengetahui pengaruh pemberian cacing sutera dengan persentase yang berbeda terhadap kelangsungan hidup dan pertumbuhan larva ikan baung $(H$. nemurus). Metode yang digunakan adalah metode ekperimen menggunakan Rancangan Acak Lengkap (RAL) dengan 4 perlakuan dan 3 ulangan yaitu, P1 (Pemberian cacing sutera 3\%/bobot ikan), P2 (Pemberian cacing sutera 6\%/bobot ikan), P3 (Pemberian cacing sutera 9\%/bobot ikan) dan P4 (Pemberian cacing sutera 12\%/bobot ikan). Ikan uji yang digunakan adalah larva ikan baung yang berumur 3 hari dengan berat rata-rata 0,02 gr dan panjang rata-rata $0,7 \mathrm{~cm}$. Larva ikan baung diperoleh dari hasil pemijahan di Balai Benih Ikan (BBI) Fakultas Pertanian Universitas Islam Riau Pekanbaru. Wadah yang digunakan adalah toples kapasitas 10 liter sebanyak 12 buah. Dari hasil penelitian diperoleh persentase kelulushidupan yang terbaik pada P4 yaitu sebesar 90\%, kemudian P3 yaitu $89 \%$, selanjutnya P2 yaitu $87 \%$ dan yang terendah pada P1 yaitu $85 \%$. Pertumbuhan berat mutlak dan panjang mutlak tertinggi terdapat pada $\mathrm{P} 4$ dengan berat 0,28 gr dan panjang $2,13 \mathrm{~cm}$, selanjutnya P3 dengan berat 0,27 gr dan panjang $2,10 \mathrm{~cm}$, kemudian P2 dengan berat 0,26 gr dan panjang 2,07 cm berikutnya yang terendah pada P1 dengan berat 0,24 gr dan panjang $2,03 \mathrm{~cm}$. Laju pertumbuhan berat harian yang tertinggi juga terdapat pada P4 yaitu 13,81\%, P3 yaitu $13,57 \%, \mathrm{P} 2$ yaitu $13,32 \%$ dan yang terendah pada P1 yaitu $13,05 \%$.

Kata kunci: Cacing Sutera, Kelangsungan Hidup, Pertumbuhan, Baung. 


\section{PENDAHULUAN}

Ikan baung (Hemibagrus nemurus) merupakan salah satu jenis ikan air tawar yang memiliki nilai ekonomis yang cukup tinggi namun populasi ikan baung di perairan umum sudah mengalami penurunan. Oleh sebab itu perlu dilakukan usaha budidaya dengan tujuan meningkatkan produksi dan mengatasi ketergantungan masyarakat terhadap ikan baung yang berasal dari hasil penangkapan di perairan umum.

Untuk mendukung kegiatan budidaya perlu diproduksi benih ikan baung yang berkualitas dalam jumlah yang banyak, melalui peningkatan kelangsungan hidup dan pertumbuhan larva ikan baung. Masalah yang sering dihadapi dalam usaha pembenihan ikan adalah tingginya tingkat mortalitas ikan pada saat fase larva dan benih, terutama pada saat larva kehabisan kuning telur. Salah satu faktor penyebab tingginya mortalitas larva ikan baung adalah ketersediaan pakan, sehubungan dengan hal itu pelu dilakukan pemberian pakan pada saat larva habis kuning telur.

Beberapa penelitian yang telah dilakukan ditemukan bahwa pakan yang terbaik untuk larva ikan baung adalah cacing sutera (Aryani et al., 2013; Priyadi et al., 2010) karena memiliki kadar protein yang cukup tinggi. Namun cacing sutera yang diberikan masih dengan cara ad libitum sehingga tidak dapat diketahui jumlah yang cukup untuk larva ikan baung, selain itu pemberian cacing sutera dengan cara ad libitum juga dapat menyebabkan menurunnya kualitas air dan terjadinya kanibalisme pada larva ikan baung jika cacing sutera yang diberikan berlebih maupun kurang. Wibowo dalam Adam (2013) menyatakan bahwa pakan yang tidak sesuai dengan jenis dan ukuran standar justru memiliki efek samping yang berbahaya.

Salah satu cara untuk mengatasi hal tersebut adalah melalui persentase cacing sutera yang diberikan ke larva ikan baung, karena dengan begitu cacing sutera yang diberikan tidak terbung dan dapat dimakan oleh larva ikan baung sesuai dengan kebutuhannya. Dharmawan dalam Adam (2013) menyatakan bahwa pakan ikan yang berkualitas tidak hanya bisa dilihat dari nilai gizinya tetapi juga dari jumlahnya. Selanjutnya Adam (2013) pemberian pakan alami cacing sutera (T. tubifex) pada ikan lele sangkuriang sebanyak $7 \%$ merupakan persentase yang terbaik dibandingkan dengan persentase $5 \%$ dan $3 \%$.
Mapaliey et al., (2013) menyatakan bahwa persentase cacing sutera yang terbaik untuk kelangsungan hidup dan pertumbuhan panjang serta berat larva ikan patin siam adalah $15 \%$ dibandingkan persentase $10 \%$ dan 5\%. Persentase pakan untuk benih lebih sering dibandingkan dengan ikan besar, karena benih lebih banyak mengkonsumsi pakan alami. persentase pakan untuk ikan yang masih kecil biasanya 3-7\% dalam sehari dan waktu pemberian pakan ditetapkan dengan memperhatikan nafsu makan ikan (Dharmawan dalam Adam, 2013). Berdasarkan hal tersebut penulis ingin melakukan penelitian tentang pengaruh pemberian cacing sutera dengan persentase yang berbeda terhadap kelangsungan hidup dan pertumbuhan larva ikan baung (H. nemurus).

\section{METODE PENELITIAN}

Penelitian ini dilaksanakan selama 21 hari yaitu dimulai pada tanggal 12 November sampai 2 Desember 2017. Bertempat di Balai Benih Ikan (BBI) Fakultas Pertanian Universitas Islam Riau Pekanbaru. Bahan yang digunakan dalam penelitian ini adalah : Larva ikan baung yang telah berumur 3 hari yang didapat dari hasil pemijahan secara buatan di BBI UIR, dengan berat awal 0,02 gr dan panjang 0,7 cm; Pakan yang diberikan pada ikan uji yaitu pakan alami berupa cacing sutera (T. tubifex) yang diperoleh dari pengumpul di daerah Sail Pekanbaru; Air yang digunakan dalam penelitian ini berasal dari sumur bor dan sudah diendapkan selam 3 hari sebelum dipakai untuk media hidup ikan uji.

Peralatan yang digunakan dalam penelitian ini adalah: Toples ukuran 10 liter sebanyak 12 buah digunakan sebagai wadah penelitian; Timbangan dengan tingkat ketelitian $0.01 \mathrm{mg}$ yang digunakan untuk menimbang berat ikan uji; Penggaris untuk pengukuran panjang ikan uji; Aerasi dengan perlengkapannya yang berguna untuk mensuplay oksigen; Tangguk besar dan kecil untuk menyerok ikan uji; Thermometer digunakan untuk mengukur suhu air; Kertas lakmus untuk mengukur $\mathrm{pH}$ air; DO meter digunakan untuk mengukur oksigen terlarut dan $\mathrm{NH}_{3}$.

Penelitian ini dimulai dari berbagai kegiatan yaitu persiapan wadah, penebaran larva ikan baung, pemberian makanan, pengukuran kualitas air, pengukuran larva dan penghitungan jumlah larva ikan.

Sebelum penelitian dilakukan, wadah yang digunakan dalam penelitian ini dibersihkan 
dengan menggunakan larutan PK (Kalium permanganat). Setelah itu wadah diisi air sebanyak 5 liter dan disusun sesuai hasil pengacakan kemudian wadah diberi aerasi untuk mensuplay oksigen. Selanjutnya setiap wadah diberi lebel sesuai hasil pengacakan perlakuan.

Larva ikan baung yang digunakan dalam penelitian ini diperoleh dari hasil pemijahan induk ikan baung secara buatan dengan menggunakan hormone LHRH (ovaprim) dengan dosis 1,5 cc. telur hasil pemijahan ditetaskan di dalam bak fiber. Setelah telur menetas kemudian larva dipelihara sampai berumur 4 hari, setelah itu dilakukan pengukuran berat dan panjang larva ikan kemudian ditebarkan ke dalam wadah penelitian dengan kepadatan 10 ekor/liter.

Pakan yang digunakan dalam penelitian ini adalah cacing sutera yang berasal dari pengumpul di daerah Sail Pekanbaru. Sebelum diberikan terlebih dahulu cacing sutera dipotong halus kemudian dicuci dengan air bersih untuk menghilangkan sisa darahnya. Setalah itu cacing sutera diberikan sesuai dengan masing-masing perlakuan yaitu 3\% untuk perlakuan I, 6\% untuk perlakuan II, 9\% untuk perlakuan III dan $12 \%$ untuk perlakuan IV. Sedangkan frekuensi pemberian pakan sebanyak 4 kali dalam satu hari, yaitu pada pagi pukul 08.00 WIB, siang 12.00 WIB, sore 16.00 WIB dan malam 20.00 WIB.

Penelitian ini menggunakan rancangan acak lengkap (RAL) yang terdiri dari 4 perlakuan dan 3 ulangan. Dimana perlakuan yang digunakan adalah sebagai berikut :

P1= Pemberian cacing sutera 3\%/bobot ikan

$\mathrm{P} 2=$ Pemberian cacing sutera 6\%/bobot ikan

P3 = Pemberian cacing sutera 9\%/bobot ikan

P4= Pemberian cacing sutera 12\%/bobot ikan
Pengamatan dan pengukuran parameter pualitas Air, pengamatan ini dilakukan untuk mengetahui perubahan yang terjadi pada kualitas air disetiap wadah penelitian, pengamatan kualitas air yang dilakukan meliputi pengukuran suhu, $\mathrm{pH}, \mathrm{DO}$ dan $\mathrm{NH}_{3}$, untuk pengukuran suhu dilakukan pada pagi, siang, sore dan malam hari, sedangkan $\mathrm{pH}$ diukur seminggu sekali, dimulai pada awal hingga akhir penelitian, kemudian $\mathrm{DO}$ dan $\mathrm{NH}_{3}$ diukur pada awal dan akhir penelitian, pergantian air dilakukan apabila air dalam wadah sudah mulai terlihat keruh.

Pengukuran dan penghitungan jumlah larva ikan, pengukuran berat larva ikan dilakukan dengan cara sampel yaitu diambil sebanyak 10 ekor dari jumlah seluruh ikan yang ada di dalam wadah penelitian, Kemudian ikan ditimbang. Sedangkan pengukuran panjang menggunakan 5 ekor ikan $(2,5 \%)$, lalu diukur panjangnya menggunakan penggaris. Sementara untuk penghitungan jumlah larva ikan dilakukan pada setiap kali pengukuran yaitu 7 hari sekali.

\section{HASIL DAN PEMBAHASAN}

\section{Kelangsungan Hidup}

Kelangsungan hidup larva ikan merupakan persentase ikan yang mampu bertahan hidup akibat pengaruh lingkungan maupun perbedaan persentase pemberian makanan. Persentase kelangsungan hidup larva ikan baung pada masing-masing perlakuan dapat dilihat pada Gambar 1.

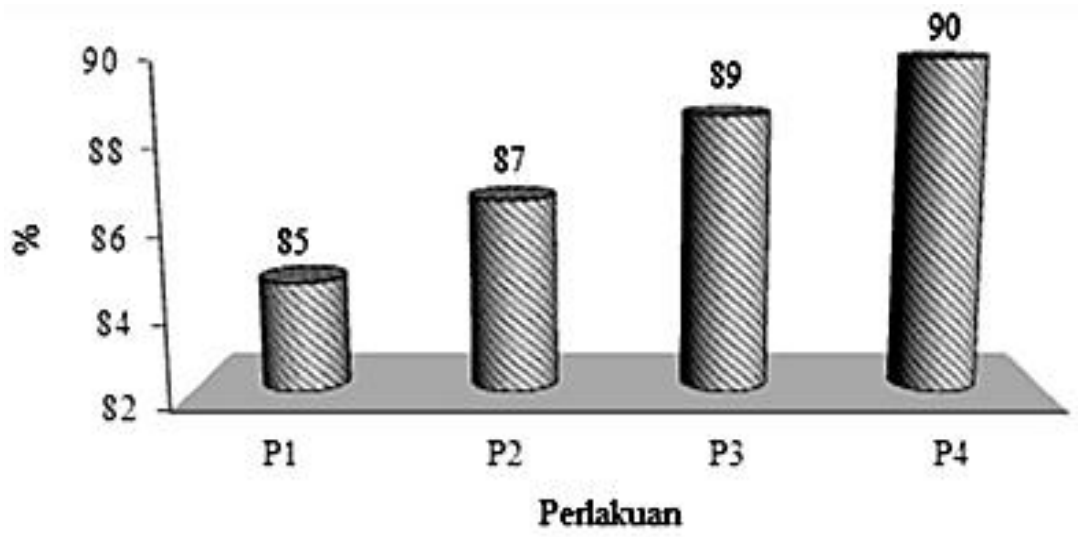

Gambar 1. Grafik Rerata Kelangsungan hidup larva Larva Ikan Baung (H. nemurus) Selama Penelitian.

Kelangsungan hidup larva ikan baung pada P4 yang diberi cacing sutera $12 \%$ lebih tinggi dari P3 dengan pemberian cacing sutera 9\%, P2 pemberian cacing sutera $6 \%$ dan yang terendah pada $\mathrm{P} 1$ dengan pemberian cacing 
sutera sebanyak 3\%. Fakta ini terjadi disebabkan karena pemberian cacing sutera pada $\mathrm{P} 4$ dapat mencukupi untuk kebutuhan makan larva ikan baung, sedangkan pada P3, P2 dan P1 cacing sutera yang diberikan masih kurang, sehingga menyebabkan terjadi kompetisi makanan antara sesama larva ikan baung.

Suhenda et al., (1993), Kelangsungan hidup ikan sangat ditentukan oleh ketersediaan pakan. Ikan akan mengalami kematian bila dalam waktu singkat tidak berhasil mendapatkan makanan, karena terjadi kelaparan dan kehabisan tenaga. Selanjutnya Hearth dan Atapaththu (2013) mengatakan bahwa kelangsungan hidup larva ikan dideterminasi oleh kombinasi berbagai faktor yang meliputi, nutrisi larva, lingkungan, imunitas kualitas air dan padat tebar penggunaan pakan juga dapat memacu pertumbuhan dan Kelangsungan hidup. Selanjutnya Herlina (2016), sintasan dipengaruhi oleh adanya faktor dalam dan faktor luar, dimana faktor yang paling dominan mempengaruhi mortalitas adalah kompetisi antar jenis, kekurangan makanan baik klualitas maupun kuantitas.

Hasil penelitian Mapaliey et al., (2013) menyatakan bahwa persentase cacing sutera yang terbaik untuk Kelangsungan hidup dan pertumbuhan panjang serta berat larva ikan patin siam adalah $15 \%$ dibandingkan persentase $10 \%$ dan $5 \%$.

Dari hasil analisis variansi yang dilakukan diperoleh F hitung $(0,44)<\mathrm{F}$ tabel 4,07 (0.05) menunjukkan bahwa pemberian cacing sutera dengan persentase berbeda tidak berbeda nyata terhadap kelangsungan hidup larva ikan baung.
Dalam usaha pembenihan ikan baung tingkat Kelangsungan hidup stadia benih masih rendah, terutama disebabkan oleh belum sesuainya pakan yang diberikan dengan kebutuhan induk dan benih yang dipelihara (Aryani et al., 2002) selanjutnya menurut Cho et al., (1985), penyediaan pakan alami untuk benih merupakan faktor penentu Kelangsungan hidup larva dalam rangka pengembangan budidaya.

Effendie dalam Herlina (2016) menyatakan bahwa kelangsungan hidup dipengaruhi oleh faktor biotik yaitu persaingan, parasit, umur, predator, kepadatan dan penanganan manusia sedangkan faktor abiotik adalah sifat fisika dan kimia dalam lingkungan perairan. Berikutya dinyatakan oleh Murdinah et al., dalam Priyadi (2010), pemberian pakan yang bermutu dan disenangi oleh ikan selain dapat mempertinggi derajat efisiensi.

\section{Pertumbuhan Berat Mutlak}

Hasil pengukuran pertambahan rata-rata berat mutlak larva ikan baung pada masingmasing perlakuan dapat dilihat pada Gambar 2.

Pertumbuhan berat mutlak larva ikan baung dari masing-masing perlakuan berbeda seperti terlihat pada Gambar 2. P4 merupakan pertumbuhan tertinggi yaitu 0,28 gr dan pertumbuhan yang terendah terdapat pada P1 yaitu 0,24 gr. Hal ini berarti bahwa Pertumbuhan berat mutlak tertinggi terjadi pada persentase pemberian cacing sutera sebanyak $12 \%$. Hal ini terjadi karena pemberian cacing sutera sebanyak $12 \%$ sudah mencukupi untuk kebutuhan makan sehingga dapat mempercepat pertumbuhan larva ikan baung.

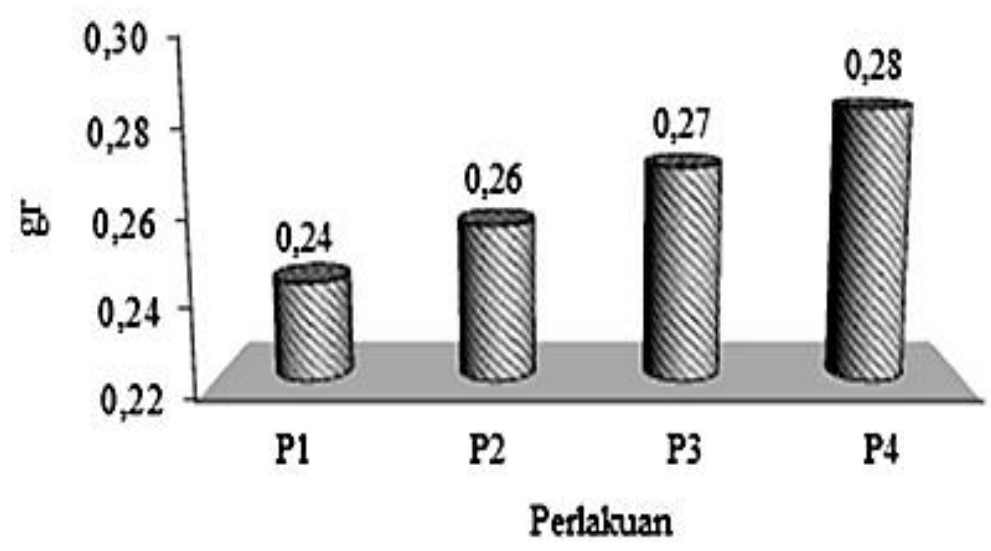

Gambar 2. Grafik Rerata Pertumbuhan Berat Mutlak Larva Ikan Baung (H. nemurus) Selama Penelitian. 
Tingginya nilai berat mutlak pada $\mathrm{P} 4$ disebabkan larva ikan baung mampu memanfaatkan pakan yang secara rutin diberikan tiap harinya. Kondisi ini disebabkankemampuan dalammengkonsumsi pakan, semakin banyak pakan yang diperoleh maka peluang ikan memperoleh makanan semakin besar, sehingga berpengaruh terhadap pertumbuhannya. Kemudian persaingan yang terjadi seperti ruang gerak dan kemampuan mendapatkan makanan dapat berlangsung secara baik tanpa mengakibatkan ikan stres dan terhambatnya pertumbuhan saat pemeliharaan (Samsul et al., 2014).

Huet (1986) menambahkan bahwa pertumbuhan terjadi karena tersedianya pakan dalam jumlah yang cukup, dimana pakan yang dikonsumsi lebih besar dari kebutuhan pokok untuk kelangsungan hidup. Selanjutnya Lovell (1988), penambahan bobot tubuh ikan juga menunjukkan bahwa kadar energi dalam pakan yang dikonsumsi ikan melebihi kebutuhan energi untuk pemeliharaan tubuh dan aktifitas lainnya.

Kecepatan pertumbuhan ikan tergantung pada jumlah pakan yang diberikan, ruang, suhu, kedalaman air dan faktor-faktor lain (Halver, 1989). Kemudian Sunarno (1991) menyatakan bahwa laju pertumbuhan bobot berhubungan dengan ketepatan antara jumlah pakan yang diberikan dengan kapasitas isi lambung. Jumlah pakan yang sesuai dengan kapasitas lambung dan kecepatan pengosongan lambung atau sesuai dengan waktu ikan membutuhkan pakan, perlu diperhatikan karena pada saat itu ikan sudah dalam kondisi lapar.

Hasil penelitian Adam (2013), pemberian pakan alami cacing sutera (T. tubifex) sebanyak 7 $\% /$ bobot tubuh ikan merupakan persentase yang terbaik untuk pertumbuhan benih ikan lele sangkuriang dibandingkan persentase 5\% dan 3\%. Sedangkan pada hasil penelitian Mapaliey et al., (2013) menyatakan bahwa persentase cacing sutera yang terbaik untuk kelangsungan hidup dan pertumbuhan panjang serta berat larva ikan patin siam adalah $15 \%$ dibandingkan persentase $10 \%$ dan $5 \%$.

Dari hasil analisis variansi yang dilakukan diperoleh $\mathrm{F}$ hitung $(2,74)<\mathrm{F}$ tabel 4,07 (0.05) menunjukkan bahwa pemberian cacing sutera dengan persentase berbeda tidak berbeda nyata terhadap pertumbuhan berat mutlak larva ikan baung.

\section{Pertumbuhan Panjang Mutlak}

Hasil pengukuran pertumbuhan panjang mutlak larva ikan baung selama penelitian pada masing-masing perlakuan disajikan dalam Gambar 3.

Pada Gambar 3. Terlihat bahwa pertumbuhan panjang mutlak larva ikan baung pada P4 (pemberian cacing sutera 12\%) menghasilkan pertumbuhan panjang tertinggi yaitu $2.13 \mathrm{~cm}, \mathrm{P} 3$ (pemberian cacing sutera 9\%) yaitu $2.10 \mathrm{~cm}, \mathrm{P} 2$ (pemberian cacing sutera $6 \%$ ) yaitu $2.07 \mathrm{~cm}$ dan yang terendah pada P1 (pemberian cacing sutera $3 \%$ ) yaitu $2.03 \mathrm{~cm}$. Berdasarkan dari data di atas bahwa pertumbuhan panjang mutlak larva ikan baung dengan pemberian cacing sutera $12 \%$ lebih baik dibandingkan dengan pemberian cacing sutera $9 \%$, 6\% dan 3\%. Hal ini disebabkan karena pemberian cacing sutera sebanyak $12 \%$ dapat mencukupi kebutuhan makan larva ikan baungsehingga meningkatkan pertumbuhan panjangnya.

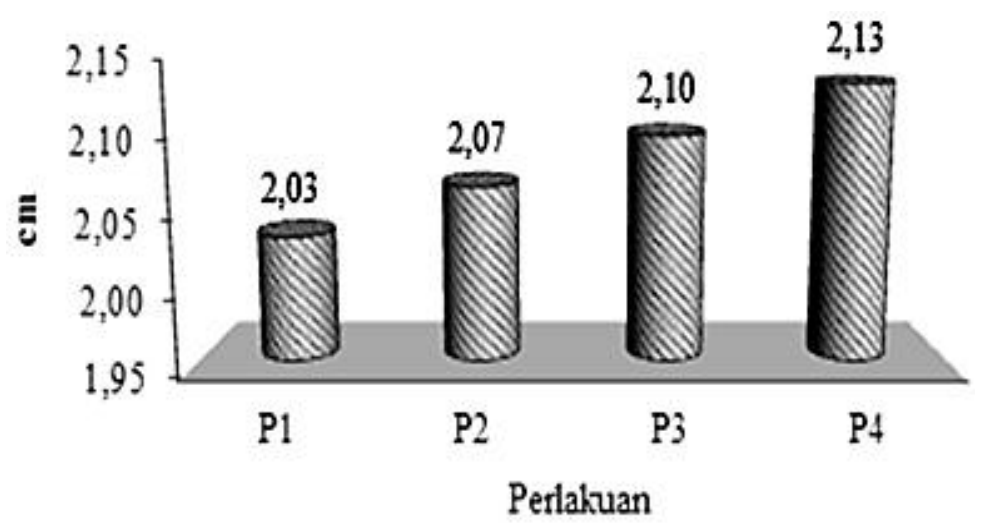

Gambar 3. Grafik Rerata Pertumbuhan Panjang Mutlak Larva Ikan baung (H. nemurus) Selama Penelitian 
Sihaili (1983) menyatakan bahwa kecepatan tumbuh tergantung, kepada jumlah makanan yang diberikan, ruang, suhu dan dalamnya air. Selanjutnya Dharma dan Suhenda dalam Purbomartono et al., (2009), faktor yang berpengaruh terhadap pertumbuhan ikan adalah faktor dalam transformasi makanan menjadi jaringan tubuh ikan seperti jumlah pakan yang dikonsumsi, laju pencernaan, frekuensi pemberian pakan, penyerapan zat makanan, serta efesiensi dan konversi pakan.

Salah satu yang mempengaruhi pertumbuhan adalah pakan dan pemberian pakan yang berkualitas baik, sehingga dapat menunjang pertumbuhan ikan (Huisman et al., 1979). Hasil penelitian Adam (2013) pemberian pakan alami cacing sutera (T. tubifex) sebanyak $7 \% /$ bobot tubuh ikan merupakan persentase yang terbaik untuk pertumbuhan benih ikan lele sangkuriang dibandingkan persentase 5\% dan 3\%. Sedangkan pada hasil penelitian Mapaliey et al., (2013) menyatakan bahwa persentase cacing sutera yang terbaik untuk kelangsungan hidup dan pertumbuhan panjang serta berat larva ikan patin siam adalah $15 \%$ dibandingkan persentase $10 \%$ dan $5 \%$.
Dari hasil analisis variansi yang dilakukan diperoleh F hitung $(0,07)<\mathrm{F}$ tabel 4,07 $(0.05)$ menunjukkan bahwa pemberian cacing sutera dengan persentase berbeda tidak berbeda nyata terhadap pertumbuhan panjang mutlak larva ikan baung.

\section{Laju Pertumbuhan Berat Harian}

Untuk mengetahui laju pertumbuhan berat harian larva ikan baung dilakukan dengan pengolahan data berat selama penelitian. Adapun data persentase laju pertumbuhan berat harian dapat dilihat pada Gambar 4.

Pertumbuhan berat harian larva ikan baung dari masing-masing perlakuan berbeda seperti terlihat pada Gambar 4. P4 merupakan pertumbuhan tertinggi yaitu $13.81 \%$, P3 yaitu $13.57 \%$, selanjutnya P2 yaitu $13.32 \%$ dan pertumbuhan yang terendah terdapat pada P1 yaitu $13.05 \%$. Dari keterangan diatas bahwa Pertumbuhan berat harian tertinggi terjadi pada persentase pemberian cacing sutera sebanyak $12 \%$. Hal ini terjadi karena pemberian cacing sutera sebanyak $12 \%$ sudah mencukupi untuk kebutuahan makan harian larva ikan baung.

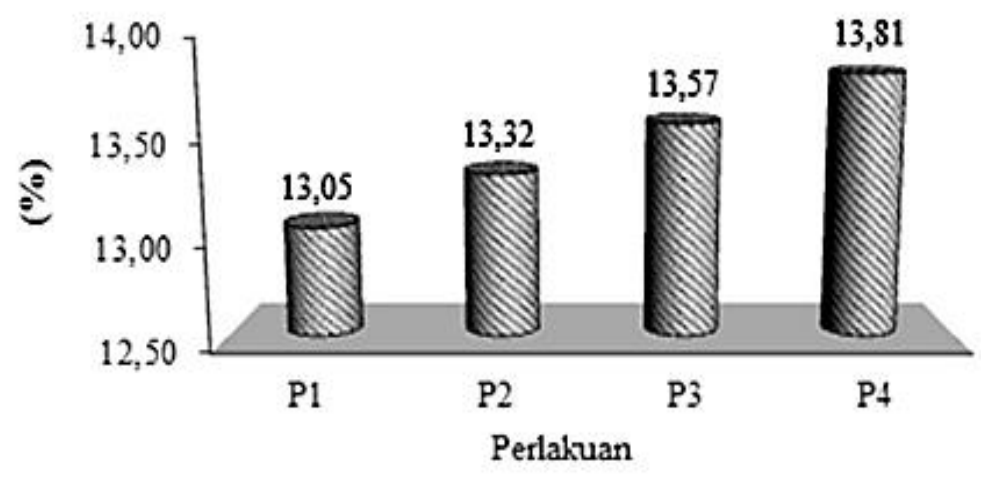

Gambar 4. Grafik Rerata Laju Pertumbuhan

Berat Harian Larva Ikan baung (H. nemurus) Selama Penelitian.

Sesuai dengan pendapat Setiawan dan Suprayudi (2003) bahwa Jumlah pakan yang mampu dikonsumsi ikan setiap harinya merupakan salah satu faktor yang mempengaruhi potensi ikan untuk tumbuh secara maksimal karena berkaitan dengan pengosogan isi perut. Selanjutnya Amalia et al., (2013). pakan yang tercerna baik akan menjadi pasokan energi yang digunakan untuk aktifias pertumbuhan.

Asma et al., (2016) menyatakan bahwa pemberian pakan dengan ransum harian yang cukup dan berkualitas tinggi serta tidak berlebihan merupakan salah satu faktor yang sangat menenukan tingkat keberhasilan usaha budidaya ikan. Kemudian. Kemudian Zonneveld et al., (1991) menyatakan bahwa ikan membutuhkan makanan untuk mendapatkan energi tubuh dan ikan akan mengalami penurunan energi tubuh yang lebih nyata jika ikan dipelihara dalam waktu yang lebih lama dalam kondisi kelaparan.

Pertumbuhan dapat dianggap sebagai hasil proses yang cendrung untuk menurunkan energy tubuh saat ikan tidak memperoleh pakan selama 
pemeliharaan dan suatu proses pemanfaatan pakan yang dikonsumsi untuk menyusun unsurunsur tubuh (Fatimah 2013).

Hasil penelitian Adam (2013) pemberian pakan alami cacing sutera (T. tubifex) sebanyak 7 $\% /$ bobot tubuh ikan merupakan persentase yang terbaik untuk pertumbuhan benih ikan lele sangkuriang dibandingkan persentase $5 \%$ dan $3 \%$. Sedangkan pada hasil penelitian Mapaliey et al., (2013) menyatakan bahwa persentase cacing sutera yang terbaik untuk kelangsungan hidup dan pertumbuhan panjang serta berat larva ikan patin siam adalah $15 \%$ dibandingkan persentase $10 \%$ dan $5 \%$.

Dari hasil analisis variansi yang dilakukan diperoleh $\mathrm{F}$ hitung $(3,75)<\mathrm{F}$ tabel 4,07 (0.05) menunjukkan bahwa pemberian cacing sutera dengan persentase berbeda tidak berbeda nyata terhadap pertumbuhan berat harian larva ikan baung.

\section{KESIMPULAN}

Berdasarkan hasil penelitian yang dilakukan dapat disimpulkan bahwa:

1. Pemberian pakan alami Cacing sutera $(T$. tubifex) dengan persentase yang erbeda tidak berpengaruh terhadap kelangsungan hidup larva ikan baung. P4 merupakan

yang tinggi yaitu mencapai 90\%, kemudian P3 yaitu 89\% selanjutnya P2 yaiu $87 \%$ dan yang terendah terdapat pada P1 yaitu $85 \%$.

2. Berat mutlak larva ikan baung untuk masing-masing perlakuan yaitu P4 sebesar 0,28 gr, P3 sebesar 0,27 gr, P2 sebesar 0,26 gr, P1 sebesar 0,24 gr dan dari berat awal tebar sebesar 0,02 gr.

3. Panjang mutlak larva ikan baung yang tertinggi terdapat pada P4 yaitu $2,13 \mathrm{~cm}$ dan yang terendah terpat pada P1 yaitu 2,03 $\mathrm{cm}$.

4. Berat harian larva ikan baung pada masingmasing perlakuan berbeda, namun nilai yang tertinggi terdapat pada $\mathrm{P} 4$ yaitu 13,81 $\%$ dan yang terendah terpat pada P1 yaitu $13,05 \%$.

\section{DAFTAR PUSTAKA}

Adam, Y. 2013. Pengaruh Pemberian Cacing Sutera (Tubifex sp), dengan Dosis yang Berbeda Terhadap Pertumbuhan Benih Ikan Lele Sangkuriang (Clarias sp). Di Balai Pengembangan Budidaya Ikan Air Tawar (BPBIAT). Provinsi Gorontalo. 32 hal.
Amalia, R, Subandiyono dan Arini, E. 2013. Pengaruh Penggunaan Papain Terhadap Tingkat Pemanfaatan Protein Pakan dan Pertumbuhan Lele Dumbo (Clarias gariepinus). Jurnal of Aquaculture Management and Technology. 2 (1): hal 136-143.

Aryani, N, Syawal H dan Bukhari D. 2002. Uji Coba Penggunaan Hormon LHRH untuk Pematangan Gonad Induk Ikan Baung (Mystus nemurus). Torani 12: 163-168.

Aryani, N, N. A. Pamungkas dan Adelina. 2013. Perbedaan Lama Waktu Pemberian Tubifeks dan Pakan Buatan Terhadap Pertumbuhan dan Sintasan Benih Ikan Baung (Mystus nemurus). Skripsi Fakultas Perikanan dan Ilmu Kelautan. Universitas Riau. Pekanbaru.

Asma, N., Z. A. Muchlisin dan I. Hasri. 2016. Pertumbuhan dan Kelangsungan Hidup Benih Ikan Peres (Osteochilus vittatus) pada Ransum Harian yang Berbeda. Jurnal Ilmiah Mahasiswa Kelautan dan Perikanan Unsyiah. (1): 1-11.

Cho, CY, Cowey CB, Wanatabe T. 1985. Fin Fish Nutrition in Asia. Ottawa.Ont.

Fatimah. 2013. Peningkatan Nafsu Makan dan Pertumbuhan pada Pendederan Ikan Kerapu Macan (Epinephelus fuscoguttatus) Melalui Periode Pemuasaan yang Berbeda. Departemen Budidaya Perairan Fakultas Pertanian dan Ilmu Kelautan Institut Pertanian Bogor. Bogor.

Halver, J. E. 1989. Fish Nutrition. Academic Press. INC, London. 789 pp.

Hearth, S, S. K.S.S. Atapaththu. 2013. Sudden Weaming of Anggel Fish Pterophyllum Scalare (Lichtenstein) (Pisces: Cichlidae) Larvae Brine Shrimp (Artemia sp) Nauplii to Formulated Larva Feed. Springer Plus 2: 102.

Herlina, S. 2016. Pengaruh Pemberian Jenis Pakan yang Berbeda Terhadap Pertumbuhan dan Kelangsungan Hidup Benih Ikan Gabus (Channa striata). Fakultas Perikanan dan Ilmu Kelautan Program Studi Budidaya Perairan Universitas Darwan Ali. Kabupaten Seruyan. Jurnal Ilmu Hewani Tropika. Vol 5.

Huet, M. 1986. Text Book of Fish Culture. Breeding and Cultivation of Fish Fishing New Book. England. 436 pp.

Huisman, E.J, M. Breterler. dan A. Vismans. 1979. Retention of Energy, Protein, Fat and Ashin Growing Carp (Cyprinus caprio) 
Unde Differen Feeding and Temperature Regimes. Procceding World Symposium on Fish Nutrition and Fish.

Lovell, R. T. 1988. Nutrition and Feeding of Fish. Van Nostrand Reinbold. New: York., p 119L

Mapaliey, N, H. Sinjal dan E. Lengkong. 2013. Pengaruh Pemberian Pakan Cacing Sutra (Tubifex sp) Dosis Berbeda Terhadap Kelulushidupan dan Pertumbuhan Larva Ikan Patin Siam (Pangasianodon hypophthalmus). Di Hatchery Balai Budidaya Air Tawar (BBAT). Tatelu. Vol. 4 (3).

Priyadi, A, E. Kusrini dan T. Megawati. 2010. Perlakuan Berbagai Jenis Pakan Alami untuk Meningkatkan Pertumbuhan dan Sintasan Larva Ikan Upside Down Catfish (Synodontis nigriventris). Balai Riset Budidaya Ikan Hias. FMIPA Unuversitas Negri Jakarta. Depok.

Purbomartono, C. Hartoyo, A. Kurniawan, 2009. Pertumbuhan Kompensasi pada Ikan Nila Merah (Oreochromis niloticus) dengan Interval Pemuasaan yang Berbeda. Jurnal Perikanan. Fakultas Perikanan dan Ilmu Kelautan Universitas Muhamadiah Purwokerto. Purwokerto. Hal 24.

Samsul, Arif A., Rusliadi dan Iskandar Putra. 2014. Pertumbuhan dan Kelulusan hidup Ikan Bawal Bintang (Trachinotus blochil) dengan Padat yang Berbeda yang Dipelihara di Keramba Jaring Apung. Fakultas Perikanan dan Ilmu Kelautan. Universitas Riau. Pekanbaru.

Setiawan, S., Suprayudi, M. A. 2003. Pertumbuhan dan Efesiensi Pakan Nila Merah (Oreochromis sp) yang Dipelihara pada Media Bersalinitas. Jurnal Akuakultur Indonesia. 2 (1):hal 27-30.

Sihaili, A. 1983. Pemeliharan Ikan dalam Keramba. Penerbit Gramedia, Jakarta.

Suhenda, N., Sumastri, S., \& Priyadi, A. 1993. Pertumbuhan Benih Ikan Lele Keli (Clarias melanoderma) yang Mendapat Pakan dengan Kadar Protein yang Berbeda. Prosiding Lokakarya Penelitian Komoditas dan Studi Khusus. Balitbangtan.

Sunarno MTD. 1991. Pemeliharaan Ikan Jelawat (Leptobarsa hoeveni) dengan Frekuensi Pemberian PakanไET£ Berbeda. Bui. Perik. Darat 10(2), 76-80.

Zonneveld, N. E., A. Huisman dan J. H. Boon. 1991. Prinsip-prinsip Budidaya Ikan. Gramedia Pustaka Utama, Jakarta. 336 hal. 
